\title{
The reasons of hyperlactatemia on admission and relationship of the lactate levels with clinical outcomes in pediatric intensive care unit
}

\author{
Çocuk Yoğun Bakım Ünitesine başvurudaki laktat yüksekliğinin nedenleri ve laktat \\ düzeylerinin klinik sonuçlarla ilişkisi
}

\author{
Özlem Bağ ${ }^{*}$, Utku Karaarslan**, Rana İşgüder**, Hurşit Apa*, İlker Devrim**, Hasan Ağın** \\ ${ }^{*}$ Dr. Behçet Uz Çocuk Hastanesi, Pediyatri Kliniği, Izmir \\ ${ }^{* *}$ Dr. Behçet Uz Çocuk Hastanesi, Çocuk Yoğun Bakım Ünitesi, Izmir \\ ${ }^{* * *}$ Dr. Behçet Uz Çocuk Hastanesi, Çocuk Enfeksiyon Hastalıkları, İzmir
}

\begin{abstract}
Purpose:Hyperlactatemia has been reported to predict mortality and morbidity in critically ill patients. The aim of this study is to define the reasons of hyperlactatemia on admission in critical pediatric patients, to describe a cut off value to predict mortality and to evaluate the outcomes of admission hyperlactatemia in pediatric intensive care unit.

Materials and methods: Hospital records of 202 pediatric patients who had admitted to pediatric intensive care unit (Male/Female: 101/101; median age: 3 years [IQR: 9.2] ) were evaluated retrospectively, for the study. Age, gender, admission diagnosis, arterial blood gas analysis, length of stay, presence of in-hospital mortality were recorded in the study group. Hyperlactatemia was defined according to L-lactate levels defined by age. The patients with and without hyperlactatemia were compared for mortality and clinical outcomes.

Results:The frequency of admission hyperlactatemia was $64.3 \%$ (n: 130). The patients with dehydration due to acute gastroenteritis, acute respiratory insufficiency and acaute cardiac insufficiency had significantly higher lactate levels compared with children with other diagnosis. Admission hyperlactatemia was not found to have a cut-off value to predict mortality by ROC analysis (Area under curve: 0.57 ). Moreover, hyperlactatemia was not found to effect either mortality rate or outcome in the study group.

Conclusion: The results of this study indicate that admission hyperlactatemia may not be used as a predictor of either death or poor clinical outcome in pediatric intensive care units. Further there is a lack of cut off value for lactate in literature to predict outcomes in different pediatric ages.
\end{abstract}

Pam Med J 2017;(1):1-6

Key words: Hyperlactatemia, admission, childhood, PICU.

Özet

Amaç: Laktat yüksekliğinin kritik hasta izleminde mortalite ve morbiditeyi belirleyici olduğunu gösteren çalışmalar mevcuttur. Bu araştırmanın amacı, kritik hastalığı olan çocuklarda laktat yüksekliğinin nedenlerini belirlemek, mortaliteyi belirleyen bir eşik değer olup olmadığını saptamak ve çocuk yoğun bakım ünitesinde laktat yüksekliğinin klinik sonuçlarını değerlendirmektir.

Gereç ve yöntem: Çocuk yoğun bakım ünitesine başvuran toplam 202 olgunun (Erkek/Kız: 101/101; median yaş: 3 [IQR: 9.2]) dosya kayıtları geriye dönük olarak incelendi. Hastaların yaşı, cinsiyeti, başvuru tanısı, arteriyel kan gazı sonuçları, hastanede kalma süresi, ve ölüm varlığı kaydedildi. Laktat yüksekliği, yaş gruplarına göre düzeylerine göre tanımlandı. Başvuruda laktat yüksekliği olan ve olmayan olgular, ölüm oranları ve klinik sonuçlar açısından karşılaştırıldı.

Bulgular: Başvuruda saptanan hiperlaktatemi sıklığı \%64.3 (n: 130) idi. Akut gastroenterite bağlı dehidratasyon, akut solunumsal yetmezlik ve akut kalp yetmezliği olanlarda laktat düzeyleri diğer tanılarla karşılaştırıldığında anlamlı olarak daha yüksek bulundu. ROC analizi ile mortaliteyi belirleyecek herhangi bir eşik değer saptanmadı (eğri altı alan: 0.57). Ayrıca, hiperlaktateminin mortalite ve klinik sonuçlarla ilişkisi olmadığı görüldü.

Sonuç: Bu çalışmanın sonuçları, çocuk yoğun bakım ünitesine başvuruda saptanan laktat yüksekliğinin ölümü ya da kötü klinik gidişi öngörmede bir belirteç olmayabileceği görüldü. Ayrıca literatürde, laktat yüksekliğinin tanımlanmasında ve belirteç olarak kullanılmasında, çocukluk çağının farklı dönemlerinde sabit bir değerin kullanılmasının önemli bir eksiklik olduğu düşünüldü.

Pam Tıp Derg 2017;(1):1-6

Anahtar sözcükler: Laktat yüksekliği, başvuru, çocukluk çağı, çocuk yoğun bakım ünitesi.

Özlam Bağ

Yazışma Adresi:Dr. Behçet Uz Çocuk Hastanesi, Pediyatri Kliniği, İzmir

e-mail: bagozlem78@yahoo.com 


\section{Introduction}

The early recognition of patients with increased risk of mortality and morbidity may result in improved patient care and better outcomes. Ease of evaluation and rapid reliable results make modern blood gas analysers ideal for a prompt assessment of the patient's metabolic status on admission to ICUs. L- lactate (2-hydroxypropanoic acid), the levo-isomer of lactate found in human body, can accurately be measured by blood gas analysers. It has been more than 150 years since lactate was first isolated from the blood samples of a woman who died from puerperal sepsis [1]. Since then, hyperlactatemia has been widely reported to be associated with critical illnesses [2-5], especially in cardiac patients [6-7]. Lactate is an end product of anaerobic metabolism and blood levels are maintained by the balance between lactate production and clearance [8]. Normal blood lactate levels are described as 0.5-1.8 $\mathrm{mmol} / \mathrm{L}$ in adults, but change by age in pediatric population [9]. Although the association of increased blood lactate levels and morbidity and mortality has been demonstrated in both adults and children, there is no agreed cut-off value for hyperlactataemia, especially in pediatric age [10].

The aim of this study is to define the reasons of hyperlactatemia on admission in critical ill pediatric patients; to describe a cut off value for pediatric age in order to predict mortality and to discuss the outcomes of patients with hyperlactatemia with literature.

\section{Materials and Methods}

\section{Study Group}

The study was conducted in Pediatric Intensive Care Unit (PICU) of Behçet Uz Children's Hospital, a tertiary hospital for pediatric patients. The data were retrospectively collected from the hospital records for all patients admitted to PICU in the course of 6 months (1 July 2012-31 December 2012), following local ethic comitee's approval (2012-03). The criteria for PICU admission were adopted from guidelines for developing admission and discharge policies for the PICUs [11]. All PICU admissions were reviewed and the patients who have arterial blood lactate levels on arterial blood gases obtained in the first 2 hours of admission constituted the study group. The patients who were diagnosed with hyperlactatemic metabolic diseases, died within first 2 hours after admission, transfered from another PICU or NICU were excluded. The patients who recieved adrenalin[12], metformin[13], nucleoside analogues[14], highvolume hemofiltration (HVHF) with lactatebuffered replacement fluids [15] were also excluded as they are known to affect lactate levels. The patients with inadequate hospital records were also excluded. If the patient was hospitalized more than one, he/she was enrolled only for the first admission.

\section{Data collection}

Age, gender, admission diagnosis, arterial blood gas analysis, length of stay at PICU and hospital, presence of in-hospital mortality were recorded in the study group. In-hospital mortality was defined as death occurring in the hospital after PICU admission while favorable outcome was defined as being discharged home; either directly from PICU or after transfer to another unit in the hospital. All collected blood samples were stored on ice, and measurements of blood lactate levels were performed immediately. Arterial blood lactate levels were measured by ABL90 Flex Blood Gas Analyzer (Radiometer Medical ApS, Åkadevej 21, DK-2700Brønshøj, Denmark). Hyperlactatemia was diagnosed according to L-lactate levels defined by age [9]. L-lactate levels were accepted high if $>$ $2.3 \mathrm{mmol} / \mathrm{L}$ in infants between $1-12$ months; $>1.5 \mathrm{mmol} / \mathrm{L}$ in toddlers and children between 1-7 years and $>0.9 \mathrm{mmol} / \mathrm{L}$ in children and adolescents older than 7 years.

\section{Statistical Analysis}

Statistical analyses were performed using IBM SPSS(ver. 18; IBM Co., Armonk, New York, USA). Data were presented as mean $\pm S D$ or median [interquartile range] according to their distribution. Qualitative variableswere expressed as percentages. Distribution of numerical data was assessed by graphical methods and Kolmogorov Smirnov test. Statistical analysis was performed with Student's t-test to compare numerical values with normal distribution. To compare numerical values with an abnormal dispersal range, interquartile ranges were assessed using Mann-Whitney U-test. Fisher's exact test and $\mathrm{Chi}^{2}$-tests were used for the comparison of categorical data. A p-value $<0.05$ 
was considered statistically significant. The efficacy to discriminate between survivors and nonsurvivors was assessed by the area under the receiver operating characteristic curve (ROC).

\section{Results}

The study group included 202 patients (Male/ Female:101/101; median age: 3 years [IQR:9.2]). Table 1 shows the patient charactheristics, mortality rates, length of PICU and hospital stay, necessity and duration of mechanical ventilation and/or inotropic support and rate of mortality. The frequency of admission hyperlactatemia was $64.3 \%(n: 130)$ in the study group. The frequency and percentages of hyperlactatemia according to age is presented on Table 2. The most frequent diseases causing hyperlactatemia were dehydration due to gastroenteritis
(21\%), respiratory insufficiency $(19 \%)$, cardiac insufficiency (18\%), respectively. Moreover, the lactate levels were significantly higher in patients with the three diagnosis ( $p$ : 0.34; $p: 0.37 ; p: 0.04$, respectively). The other reasons of hyperlactatemia in the study group were diabetic ketoacidosis, sepsis, drug intoxication, renal insufficiency and trauma (Table 3). In the study group, admission hyperlactatemia was not found to have a cut-off value to predict mortality by ROC analysis (Area under curve:0.57) (Figure 1). The analysis continued to compare the rate of mortality, PICU stay duration, hospital stay duration, MV necessity and duration, inotropic support and duration in patients with and without hyperlactatemia. There were no statistical difference between the two groups for the compared parameters $(p>0.05)$ (Table 4$)$.

Table 1. The patient characteristics of the study group

\begin{tabular}{ll}
\hline Age $^{*}$ & 3 [IR:9.2] \\
Gender (Male /Female) & $101 / 101$ \\
Hospital stay duration* (days) & $8[\mathrm{IR}: 14]$ \\
PICU stay duration* & $2[\mathrm{IR}: 4]$ \\
MV necessity & $30 / 202$ \\
Inotrop necessity & $33 / 202$ \\
Mortality rate & 0.09 \\
\hline *Median with Interquartile Range & \\
\hline
\end{tabular}

Table 2. The normal $L$ lactate values by age and the distribution of the study group according to age.

\begin{tabular}{lccc}
\hline Age & Normal lactate values* & Frequency $(\mathbf{n})$ & Percentage $(\%)$ \\
\hline$<1$ & $1.1-2.3$ & 52 & 25.7 \\
$1-7$ & $0.8-1.5$ & 80 & 39.6 \\
$>7$ & $0.6-0.9$ & 70 & 34.7 \\
\hline${ }^{*} \mathrm{mmol} / \mathrm{L}$ & & & \\
\hline
\end{tabular}

Table3. The diagnosis of patients with admission hyperlactatemia (n:130)

\begin{tabular}{lc}
\hline Acute gastroenteritis & $25(20.7 \%)$ \\
Respiratory insufficiency & $24(19.2 \%)$ \\
Cardiac insufficiency & $21(18.4 \%)$ \\
Diabetic ketoacidosis & $16(12.3 \%)$ \\
Sepsis & $14(10.7 \%)$ \\
Drug intoxication & $11(8.4 \%)$ \\
Renal insufficiency & $10(7 \%)$ \\
Seizures & $7(5 \%)$ \\
Trauma & $2(1.5 \%)$ \\
Total & $130(100 \%)$ \\
\hline
\end{tabular}




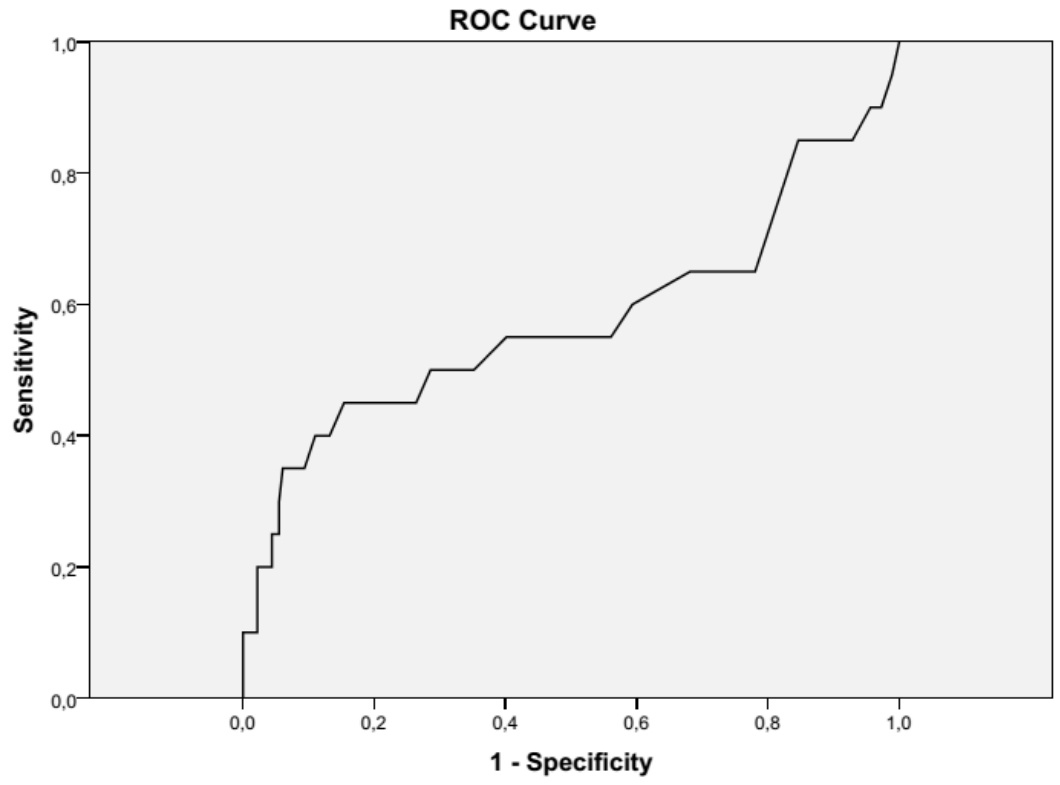

Figure 1. The Area Under Curve showed no cut-off value to predict mortality by ROC analysis (Area under curve:0.57).

Table4. The effect of admission hyperlactatemia on mortality and clinical outcome.

\begin{tabular}{lccc}
\hline & Normal lactate levels & Hyperlactatemia & $\mathbf{p}$ \\
\hline & $(\mathrm{n}: 77)$ & $(\mathrm{n}: 130)$ & \\
Mortality & $8 / 72$ & $12 / 130$ & 0.58 \\
PICU stay duration* & $3[5]$ & $2[3]$ & 0.80 \\
Hospital stay duration* $^{*}$ & $8[17]$ & $8[13]$ & 0.40 \\
MV necessity & $12 / 72$ & $18 / 130$ & 0.36 \\
MV duration* & $3[23]$ & $2[6]$ & 0.14 \\
Inotropic support necessity & $17 / 77$ & $16 / 130$ & 0.76 \\
& & &
\end{tabular}

\section{Discussion}

The results of this study indicates that admission hyperlactatemia can not be used as a predictor of either death or poor clinical outcome in PICUs. The incidence of admission hyperlactatemia was $64 \%$ in the study group and $25 \%$ of them was under age 1 . We hypotessed that admission hyperlactatemia is related with increased mortality, poor clinical outcome, increased PICU and hospital stay but our results did not support our hypothesis.

Literature includes conflicting reports on hyperlactatemia and mortality and/or clinical outcome. As a matter of fact, hyperlactatemia was firstly reported as a parameter for measurement of "reversibility"[16]. Then, in recent years, most reports show a prognostic value of hyperlactatemia on predicting mortality in both adults and children in lots of medical illnesses, including shock, sepsis, trauma, surgery and especially after cardiac interventions [17-22]. Although there are reports that admission hyperlactatemia predicts mortality and clinical outcome, the predictive value of a single lactate assessed on admission is controversial. Several studies have shown no significant predictive value of admission lactate [23-24]. Recent reports offer to follow the upward or downward trend in lactate, or the duration of hyperlactatemia, by serial measurement after admission. Lactate clearance is defined as 'the ability to clear lactate to normal levels' used for more than 20 years in critical care literature [25]. Some authors suggest to use the term 'lactate shift' or 'lactate kinetics' due to physiologic sense [26]. Whatever it is called, physiological and pathological factors affecting lactate production and clearance in the presence of multiorgan failure confounds to a prognostic interpretation of a single measurement [27]. 
Another important issue is that, there is no cut- off value for lactate to predict mortality in pediatric age. Setting the cut off point for lactate in order to predict patient outcome, is a question of getting the optimal relationship between sensitivity and specificity. In most reports, lactate levels $>2 \mathrm{mmol} / \mathrm{L}$ was accepted to be high. Bai et al [28] reported, a sensitivity of $94 \%$ and a specificity of $24 \%$ for predicting in-hospital mortality, at the cut-off value of $>2.0 \mathrm{mmol} / \mathrm{l}$ and the positive and negative likelihood ratios were 1.2 and 0.25 , respectively. Some reports suggest that a lactate level of greater than 4 $\mathrm{mmol} / \mathrm{L}$, instead of $2 \mathrm{mmol} / \mathrm{L}$, should be used to define hyperlactatemia to predict death [29]. Nichol et al [30], reported that high blood lactate concentrations within the current reference range were also associated with increased hospital mortality. In our study group, admission hyperlactatemia was not found to have a cutoff value to predict mortality by ROC analysis (Area under curve:0.57) (Figure 1). Continuing analysis by dividing the patients into two groups as hyperlactatemia and normolactatemia revealed no stastistical differences between two groups. L-lactate levels were accepted high if $>$ $2.3 \mathrm{mmol} / \mathrm{L}$ in infants between 1- 12 months; $>1.5 \mathrm{mmol} / \mathrm{L}$ in toddlers and children between $1-7$ years and $>0.9 \mathrm{mmol} / \mathrm{L}$ in children and adolescents older than 7 years. We suggest that a single cut-off value can not be used in pediatric age, as normal values of L-lactate levels differ by age due to physiologic maturation of glycolytic enzymes. The current report is the only study in literature using different values for different pediatric ages to define hyperlactatemia.

Although the literature consist of many studies evaluating the predictive effect of lactate on mortality, there are only a few reports about lactate and clinical morbidity. A recent study, conducted among out-hospital cardiac arrest patients, has shown that the use of lactate as a predictor of survival or neurological outcome is not recommended [31]. Kliegel et al. reported that sustained hyperlactatemia (>2.0 mM after 48 hours) was predictive for mortality as well as poor neurological outcome[32]. In our study, we evaluated the necessity and duration of mechanical ventilation and fluid resuscitation but there were no statistical difference between the patients with and without admission hyperlactatemia. We suggest that, in pediatric age, the causes of hyperlactatemia differ from adults. The most common causes in our study group were dehydration due to acute gastroenteritis, respiratory insufficiency mostly due to acute respiratory infections which can rapidly respond to appropiate treatments.

In conclusion, although the effect of lactate guided treatment was studied in a randomized controlled study of ICU patients [33], it may not be necessary in pediatric age. The limitation of our study is its retrospective design. In our clinic, blood gas analysis are transfered with ice and performed within 10 minutes as a protocol but we can not exclude preanalytic errors, exactly. Thus, prospective studies are needed to define cut-off values for lactete, as there is a lack of knowledge in literature on this issue for different pediatric ages.

Conflict of interest: The authors declare no conflict of interest.

\section{References}

1. Kompanje EJ, Jansen TC, van der Hoven B, Bakker J. The first demonstration of lactic acid in human blood in shock by Johann Joseph Scherer (1814 -1869) in January 1843. Intensive Care Med 2007;33:19671971.

2. Weil MH, Afifi AA. Experimental and clinical studies on lactate and pyruvate as indicators of the severity of acute circulatory failure (shock). Circulation 1970;41:989-1001.

3. Jansen TC, Van Bommel J, Bakker J. Blood lactate monitoring in critically ill patients: a systematic health technology assessment. Crit Care Med 2009;37:28272839.

4. Kruse O, Grunnet N, Barfod C. Blood lactate as a predictor for in-hospital mortality in patients admitted acutely to hospital:a systematic review. Scand J Trauma Resusc Emerg Med 2011;19:74.

5. Koliski A, Cat I, Giraldi DJ, Cat ML. Blood lactate concentration as prognostic marker in critically ill children. Article in Portuguese. J Pediatr (Rio J) 2005;81:287-292.

6. Lazzeri C, Valente S, Chiostri M, Gensini GF. Clinical significance of lactate in acute cardiac patients. World J Cardiol. 2015;26:483-489.

7. Mak NT, Iqbal S, de Varennes B, Khwaja K. Outcomes of post-cardiac surgery patients with persistent hyperlactatemia in the intensive care unit: a matched cohort study. J Cardiothorac Surg. 2016;24:33.

8. De Backer D. Lactic acidosis. Minerva Anestesiol 2003;69:281-284.

9. Stanley FL. Reference intervals for laboratory tests and procedures. In: Kliegman RM, Stanton BM, St 
Geme JW, Schor FN, Behrman RE (Ed). Nelson Textbook of Pediatrics, $20^{\text {th }} \mathrm{Ed}$, International Edition, Vol 1, Saunders Elsevier Health, 2016;3464-3473.

10. Fine-Goulden MR, Durward A. How to use lactate. Arch Dis Child Educ Pract Ed 2014;99:7-22.

11. Guidelines for developing admission and discharge policies for the pediatricintensive care unit. American Academy of Pediatrics. Committee on Hospital Careand Section of Critical Care. Society of Critical Care Medicine. Pediatric Section Admission Criteria Task Force. Pediatrics 1999;103:840-842.

12. Day NP, Phu NH, Bethell DP, et al. The effects of dopamine and adrenaline infusions on acid-base balance and systemic haemodynamics in severe infection. Lancet 1996;348:219-223.

13. Chang CT, Chen YC, Fang JT, Huang CC. Metforminassociated lactic acidosis: case reports and literature review. J Nephrol 2002;15:398-402.

14. Falco V, Crespo M, Ribera E. Lactic acidosis related to nucleoside therapy in HIV-infected patients. Expert Opin Pharmacother 2003;4:1321-1329.

15. Cole L, Bellomo R, Baldwin I, Hayhoe M, Ronco C. The impact of lactate buffered high-volume hemofiltration on acid-base balance. Intensive Care Med 2003;29:11131120.

16. Broder G, Weil MH. Excess Lactate: An index of reversibilityof shock in human patients. Science 1964;143:1457-1459.

17. Jansen TC, van Bommel J, Mulder PG, et al. Prognostic value of blood lactate levels: does the clinicaldiagnosis at admission matter? J Trauma 2009;66:377-385.

18. Juneja D, Singh O, Dang R. Admission hyperlactatemia: causes, incidence, andimpact on outcome of patients admitted in a general medical intensive care unit. J Crit Care 2011;26:316-320

19. Husain FA, Martin MJ, Mullenix PS, Steele SR, Elliott $D C$ : Serum lactate and base deficit as predictors of mortality and morbidity. Am J Surg 2003,185:485-491

20. Basaran M, Sever K, Kafali E, et al: Serum lactate level has prognostic significance after pediatric cardiac surgery. J Cardiothorac Vasc Anesth 2006;20:43-47.

21. Cerovic O, Golubovic V, Spec-Marn A, Kremzar B, Vidmar G. Relationship between injury severity and lactate levels in severely injured patients. Intensive Care Med 2003;29:1300-1305.

22. Khosravani $H$, Shahpori R, Stelfox $H T$, Kirkpatrick AW, Laupland KB. Occurrence and adverse effect on outcome of hyperlactatemia in the critically ill. Crit Care 2009;13:90.

23. Arnold RC, Shapiro NI, Jones AE, et al. Emergency Medicine Shock Research Network (EMShockNet) Investigators. Multicenter study of early lactate clearance as a determinant ofsurvival in patients with presumed sepsis. Shock. 2009;32:35-39.
24. James JH, Luchette FA, McCarter FD, Fischer JE. Lactate is an unreliableindicator of tissue hypoxia in injury or sepsis. Lancet 1999; 354:505-508.

25. Abramson D, Scalea TM, Hitchcock R, Trooskin SZ, Henry SM, Greenspan J.Lactate clearance and survival following injury. J Trauma. 1993;35:584-588.

26. Walker CA, Griffith DM, Gray AJ, Datta D, Hay AW. "Lactate Shift," Rather Than "Lactate Clearance," for Serial Blood Lactate Monitoring? Crit Care Med. 2015;43:596.

27. Hatherill M, McIntyre AG, Wattie M, Murdoch IA. Early hyperlactataemia incritically ill children. Intensive Care Med. 2000;26:314-318.

28. Bai Z, Zhu X, Li M,et al. Effectiveness ofpredicting inhospital mortality in critically ill children by assessing blood lactate levels at admission. BMC Pediatr 2014;28:83.

29. Berend K, Develter W. Admission hyperlactatemia in intensive care units and mortality. J Crit Care 2011;26:321-322

30. Nichol AD, Egi M, Pettila V, et al. Relative hyperlactatemia and hospital mortality in critically ill patients: a retrospective multi-centre study. Crit Care2010;14:25

31. Williams TA, Martin R, Celenza A, et al. Use of serum lactate levels to predict survival for patients withoutof-hospital cardiac arrest: A cohort study. Emerg Med Australas 2016;28:171-178.

32. Kliegel A, Losert $H$, Sterz $F$, et al. Serial lactate determinations for prediction of outcome after cardiac arrest. Medicine (Baltimore) 2004;83:274-279.

33. Jansen TC, van BJ, Schoonderbeek FJ, et al: Early lactate-guided therapy in intensive care unit patients: a multicenter, open-label, randomized controlled trial. AmJ Respir Crit Care Med 2010;182:752-761. 